\title{
Effect of flunixin meglumine alone and in combination on haemodynamics during bovine endotoxic shock and after treatment
}

\author{
Digvijay Singh, Satish Kumar Bansal, Gurbrinderjit Singh Ghumman
}

Department of Veterinary Physiology \& Biochemistry, College of Veterinary Science, Guru Angad Dev Veterinary and Animal Sciences University, Ludhiana, India.

Email: digvijay231@rediffmail.com

Received 21 July 2010; revised 26 August 2010; accepted 30 August 2010.

\section{ABSTRACT}

To investigate the effect of Flunixin meglumine- a NSAID; alone and in combination with hypertonic saline on endotoxemic buffalo calves, two groups of five apparently healthy male buffalo calves aged between 6-8 months were subjected to I.V. infusion of E.coli endotoxin at the rate of $5 \mu \mathrm{g} / \mathrm{kg}$ BW per hour for 3 hours. A highly significant $(P<0.01)$ fall in mean systolic,diastolic, pulse, mean arterial pressure (M.A.P), central venous pressure (C.V.P) and haemoglobin was observed till the end of endotoxin infusion while respiratory rate was significantly elevated along with a non-significant alteration in rectal temperature and hematocrit during the infusion of endotoxin. Immediately at the end of endotoxin infusion, flunixin meglumine at the rate of $1.1 \mathrm{mg} / \mathrm{kg} \mathrm{B.W}$ was infused i.v. in group-I animals and group-II animals were infused with hypertonic saline solution (H.S.S.) at the rate of $4 \mathrm{ml} / \mathrm{Kg} \mathrm{BW}$ as one time infusion followed by flunixin meglumine at the rate of $1.1 \mathrm{mg} / \mathrm{kg}$ B.W which resulted in increase of various parameters either to normal or very close to normal value while the rectal temperature and haematocrit decreased non-significantly throughout the observation period of 7 hours. No improvement in $\mathrm{Hb}$ and respiration was observed consequent to FM administration. Both treatments successfully raised systolic, diastolic, pulse pressure, C.V.P \& M.A.P to normal pre-infusion values. From the results of the present investigation, it can be concluded that i.v. infusion of FM alone and in combination with hypertonic saline solution in endotoxemic buffalo calves effectively restores the various hemodynamic parameters close to normal pre-infusion values and it can be used as immediate resuscitation measure to provide the clinician valuable time to plan further long term treatment.
Keywords: Buffalo Calves; Flunixin Meglumine; Haemodynamics; Hypertonic Saline; Endotoxic Shock

\section{INTRODUCTION}

Endotoxemia is a potentially devastating complication of several diseases of cattle e.g. enteric disease, septicemia, metritis, mastitis and pneumonia [1]. Endotoxemia is a life threatening inflammatory condition which can lead to shock, multiple organ failure, suppression of immune system and wound healing processes [2]. After gaining access to the circulation, endotoxin causes a variety of adverse effects including cardiovascular compromise, lactic acidiosis, leukopenia, glucose dyshomeostasis, hemostatic alteration, gastrointestinal,respiratory and renal disturbances. The traditional treatment for endotoxemic animals attempts to support cardiac and pulmonary function, eliminate causative microbes and modulate the production of endogenous mediators. While hypertonic saline is cheap, easily available and has been reported to bring immediate beneficial effects which are transient [3], flunixin meglumine inhibits the release of endogenous inflammatory mediators. The present investigation was carried out to elucidate the effects of flunixin meglumine- a NSAID alone and in combination with hypertonic saline solution on hemodynamics of endotoxemic buffalo calves.

\section{MATERIALS AND METHODS}

Normal healthy male buffalo calves (10) divided into two groups of 5 each, aged between 6-8 months with body weight range $70-110 \mathrm{~kg}$ procured from local market were dewormed a week before the experiment with fenbendazol at the rate of $5 \mathrm{mg} / \mathrm{kg}$ B.W.The E-coli endotoxin(lyophilized, phenol extracted 0111: $\mathrm{B}_{4}$ lipopolysaccharide, SIGMA chemicals, USA) was reconstituted by dissolving it in $0.9 \%$ normal saline to make a stock-solution of $1 \mathrm{mg} / \mathrm{ml}$. Endotoxin concentration of 5 
$\mu \mathrm{g} / \mathrm{ml}$ was prepared by dissolving $1 \mathrm{ml}$ of stock solution in $199 \mathrm{ml}$ of normal saline. Endotoxin was $\mathrm{I} / \mathrm{v}$ infused in the animals at the rate of $5 \mu \mathrm{g} / \mathrm{kg} \mathrm{BW} / \mathrm{hr}$ for $3 \mathrm{hrs}$ was followed immediately with infusion of flunixin meglumine at the rate of $1.1 \mathrm{mg} / \mathrm{kg} \mathrm{BW}$ in group-I and with hypertonic saline solution ( $7.2 \% \mathrm{Nacl}$ acq. $)$ at the rate of $4 \mathrm{ml} / \mathrm{Kg}$. BW followed by flunixin meglumine at the rate of $1.1 \mathrm{mg} / \mathrm{kg}$ BW in group-II as one time infusion.

The animals were casted in right lateral recumbency on the operation table. Before endotoxin infusion, an area over the jugular furrow was shaved and disinfected with savlon. The local anaesthetic lignocaine (2\%) at the rate of $90 \mathrm{ml}$ was injected subcutanaeously and intramuscularly before catheterization of the carotid artery and jugular vein to alleviate pain. The skin was incised to expose and catheterize the carotid artery and jugular vein. Siliconized polyethylene catheter was inserted into the carotid artery and was connected to mercury manometer through a 3-way cannula with stop cork for the record of arterial blood pressure. The jugular vein was catherterized and attached to the saline manometer (Ramson's scientific and surgical India Pvt. Ltd, Agra-India) for the record of CVP and administration of endotoxin and flunixin meglumine.

Packed cell volume was estimated by microhaemotocrit method while $\mathrm{Hb}$ was measured by cyannomethaemoglobin method by the use of spectrophotometer by colorimetric method at $540 \mathrm{~mm}$ [4]. Body temperature was recorded by using standard clinical thermometer from the rectum of the animal. Thermometer was in touch with the mucosa for one minute during every observation.

The data were pooled and analyzed using Completely Randomized Design ANOVA and t-test [5]. All the values obtained were compared with the pre-infusion normal values within the group.

\section{RESULTS AND DISCUSSION}

The I.V. infusion of endotoxin in animals led to the development of clinical symptoms of restlessness, respiratory distress characterized by labored and abdominal respiration, diarrhea and profuse salivation. The animals closed their eyes and struggled intermittently with the progression of endotoxin infusion. On i.v. infusion of hypertonic saline solution and flunixin meglumine, all the animals opened their eyes and were alert. A profuse urination was observed one hour after hypertonic saline solution infusion in group-II animals.

The normal mean systolic pressure was observed to be $161.2 \pm 11.36 \mathrm{mmHg}$ (Table 1) and $154.40 \pm 4.07$ $\mathrm{mmHg}$ (Table 2) which is slightly higher than $145.60 \pm$ 17.3 to $146.60 \pm 2.78 \mathrm{mmHg}$ as reported in buffalo calves [3]. The mean systolic pressure decreased immediately after endotoxin infusion. An increase in systolic pressure was seen on treatment with flunixin meglumine
(FM) and it remained non-significantly below the normal values (Table 1, Figure 1). Similar results have been reported by Singh et al., 2005 [6].

The normal mean diastolic pressure was $124.00 \pm$ $13.18 \mathrm{mmHg}$ (Table 1) and $110.80 \pm 4.45 \mathrm{mmHg}$. (Table 2) which is close to $118.0 \pm 7.80$ to $122.40 \pm 7.4$ $\mathrm{mmHg}$ as reported. [3]. The diastolic pressure was significantly $(\mathrm{P}<0.01)$ lower at $3^{\text {rd }}$ hour of start of endotoxin infusion (Table 1). Similar results have been reported in buffalo calves $[3,6]$. After flunixin meglumine treatment, the diastolic pressure reached slightly above normal value at the end of the experiment i.e. $7^{\text {th }}$ hour of observation (Table 1).

The normal pulse pressure was $35.20 \pm 5.60 \mathrm{mmHg}$ (Table 1) and $44.0+8.10 \mathrm{mmHg}$ (Table 2). Apart from a general decline in pulse pressure, a significantly $(\mathrm{P}<$ 0.01 ) lower pulse pressure was observed at 3 hour of start of endotoxin which after treatment increased and was non-significantly lower than the normal pre-infusion level throughout the period of observation in group-1 while in group-2 pulse pressure was significantly below normal pre-infusion values throughout the observation period. Endotoxin infusion lowered the pulse pressure and treatment with flunixin meglumine led to an increase in pulse pressure, yet it was still lower then the normal value at the end of the experiment (Table 1).

The normal MAP (Mean arterial pressure) was found to be $135.73 \pm 12.02$ (table 1) and $126.52 \pm 3.35 \mathrm{mmHg}$ which is similar to $130.00 \pm 6.4 \mathrm{~mm} \mathrm{Hg}$ [6] but lower than $153.88 \pm 2.00 \mathrm{mmHg}$ [7]. The fall in MAP throughout endotoxin infusion was significant i.e., upto $3^{\text {rd }}$ hour and after infusion of Flunixin meglumine, it was slightly higher than the normal value at the end of the experiment (Table 1). The fall in MAP during endotoxin infusion may be due to the release of 6 -Keto prostaglandin-F1- $\alpha$ [8]. The rise in MAP after HSS infusion may be due to the fact that HSS infusion increases the plasma osmolality and osmiotically draws intracellular and interstitial water into vascular space. The consequent plasma volume expansion is $3 \mathrm{ml}$ for every $1 \mathrm{ml}$ of hypertonic saline solution infused [9]. This rapid plasma volume expansion increases the cardiac output and the mean arterial pressure. Hypertonic saline may also elicit a beneficial effect through reduction of endothelial swelling which results in narrowed vessel diameter with increased hydraulic resistance making perfusion of tissues more difficult. According to Olson et al. (1995) [10], in response to endotoxin, through the action of a membrane bound enzyme prostaglandin synthase, arachidonic acid is converted to cyclicendoperoxidases i.e., $\mathrm{PGG}_{2}$ and $\mathrm{PGH}_{2}$ which are rapidly converted into Thromboxane $\mathrm{A}_{2}\left(\mathrm{TXA}_{2}\right)$ and $\mathrm{PGI}_{2}$. $\mathrm{PGI}_{2}$ is a potent systemic vasodilator which could contribute to endotoxininduced systemic hypotension and lethality. The rise in 
Table 1. Different haemodynamic parameters at different stages of endotoxic shock and after treatment with flunixin meglumine. (Group-I).

\begin{tabular}{|c|c|c|c|c|c|c|c|c|}
\hline \multirow[b]{2}{*}{ Parameter } & \multicolumn{4}{|c|}{ Endotoxic Shock } & \multicolumn{4}{|c|}{ After Treatment } \\
\hline & 0 hr & $1 \mathrm{hr}$ & $2 \mathrm{hr}$ & $3 \mathbf{h r}$ & $4 \mathrm{hr}$ & 5 hr & $6 \mathrm{hr}$ & $7 \mathrm{hr}$ \\
\hline $\begin{array}{l}\text { Systolic pressure } \\
(\mathrm{mmHg})\end{array}$ & $161.20 \pm 11.36$ & $122.80 * \pm 11.02$ & $123.60 * \pm 2.79$ & $111.60 * \pm 3.49$ & $154.00 \pm \_9.01$ & $158.40 \pm 7.76$ & $157.20 \pm 7.63$ & $155.60 \pm 7.93$ \\
\hline $\begin{array}{l}\text { Diastolic pressure } \\
(\mathrm{mmHg})\end{array}$ & $124.00 \pm 13.18$ & $98.00 \pm 14.94$ & $100.00 \pm 8.17$ & $93.20 * \pm 5.08$ & $122.40 \pm 4.80$ & $129.20 \pm 8.64$ & $132.40 \pm 10.17$ & $126.40 \pm 12.02$ \\
\hline $\begin{array}{l}\text { Pulse pressure } \\
(\mathrm{mmHg})\end{array}$ & $35.20 \pm 5.60$ & $24.80 \pm 5.82$ & $23.60 \pm 6.11$ & $18.40 * \pm 3.54$ & $31.60 \pm 4.12$ & $29.20 \pm 4.22$ & $24.80 \pm 3.93$ & $29.20 \pm 6.56$ \\
\hline $\begin{array}{c}\text { Mean Arterial } \\
\text { pressure (mmHg) }\end{array}$ & $135.73 \pm 12.02$ & $106.26 * \pm 13.48$ & $107.86^{*} \pm 6.23$ & $101.33 * \pm 5.34$ & $132.93 \pm 8.04$ & $139.06 \pm 0.10$ & $140.66 \pm 9.21$ & $136.13 \pm 10.38$ \\
\hline $\begin{array}{l}\text { Central venous } \\
\text { pressure }(\mathrm{Cm})\end{array}$ & $3.10 \pm 0.93$ & $-0.90 * \pm 1.25$ & $-0.70 * \pm 1.41$ & $-0.20 * \pm 1.98$ & $4.50 \pm 1.06$ & $2.80 \pm 1.59$ & $1.50 \pm 1.48$ & $-0.60 \pm 1.36$ \\
\hline $\begin{array}{l}\text { Respiration rate } \\
(\mathrm{movt} / \mathrm{min})\end{array}$ & $11.80 \pm 1.20$ & $10.20 \pm 1.74$ & $21.40 * \pm 2.46$ & $21.00 * \pm 1.61$ & $14.80 \pm 1.16$ & $14.80 \pm 1.50$ & $14.60 \pm 1.86$ & $14.60 \pm 1.43$ \\
\hline $\begin{array}{l}\text { Body temperature } \\
\qquad(\mathrm{F})\end{array}$ & $100.88 \pm 0.69$ & $100.32 \pm 0.95$ & $100.72 \pm 0.99$ & $100.76 \pm 0.97$ & $100.32 \pm 0.83$ & $100.18 \pm 0.75$ & $100.22 \pm 0.80$ & $100.32 \pm 0.72$ \\
\hline $\begin{array}{l}\text { Hematocrit } \\
(\mathrm{PCV})(\%)\end{array}$ & $35.20 \pm 1.43$ & $34.20 \pm 1.20$ & $33.00 \pm 1.14$ & $32.20 \pm 1.24$ & $33.40 \pm 1.29$ & $33.80 \pm 0.97$ & $33.40 \pm 1.17$ & $33.80 \pm 1.07$ \\
\hline $\begin{array}{l}\text { Hemoglobin } \\
\quad(\mathrm{g} 1 \mathrm{dl})\end{array}$ & $12.51 \pm 0.28$ & $12.19 \pm 0.25$ & $11.87 \pm 0.24$ & $11.57 * 0.18$ & $11.97 \pm 0.14$ & $12.36 \pm 0.20$ & $11.97 \pm 0.10$ & $12.01 \pm 0.08$ \\
\hline
\end{tabular}

*Significant at $1 \%$ level; No. of animals $=5$.

Table 2. Different haemodynamic parameters during different stages of endotoxic shock and after treatment with hypertonic saline and Flunixin meglumine. (Group-II).

\begin{tabular}{|c|c|c|c|c|c|c|c|c|}
\hline \multirow[b]{2}{*}{ Parameter } & \multicolumn{4}{|c|}{ Endotoxic Shock } & \multicolumn{4}{|c|}{ After Treatment } \\
\hline & 0 hr & $1 \mathrm{hr}$ & $2 \mathrm{hr}$ & $3 \mathrm{hr}$ & $4 \mathrm{hr}$ & 5 hr & $6 \mathrm{hr}$ & $7 \mathrm{hr}$ \\
\hline $\begin{array}{l}\text { Systolic pressure } \\
(\mathrm{mmHg})\end{array}$ & $154.40 \pm 4.07$ & $129.6 * \pm 10.30$ & $89.60 * \pm 10.25$ & $92.80 * \pm 7.12$ & $134.60 \pm 6.44$ & $137.60 \pm 7.83$ & $138.00 \pm 10.10$ & $138.00 \pm 10.15$ \\
\hline $\begin{array}{l}\text { Diastolic pressure } \\
(\mathrm{mmHg})\end{array}$ & $110.80 \pm 4.45$ & $101.20 \pm 5.59$ & $77.20 * \pm 7.75$ & $71.20 * \pm 5.05$ & $108.80 \pm 9.90$ & $106.40 \pm 6.06$ & $113.20 \pm 7.24$ & $111.60 \pm 6.67$ \\
\hline $\begin{array}{l}\text { Pulse pressure } \\
(\mathrm{mmHg})\end{array}$ & $44.00 \pm 8.10$ & $30.00 \pm 6.40$ & $14.40 * \pm 2.45$ & $20.80 * \pm 3.35$ & $25.60 * \pm 4.48$ & $29.20 * \pm 14.10$ & $26.80 * \pm 13.40$ & $28.40 * \pm 14.20$ \\
\hline $\begin{array}{l}\text { Mean Arterial } \\
\text { pressure (MAP) } \\
(\mathrm{mmHg})\end{array}$ & $126.52 \pm 3.35$ & $108.2 * \pm 5.35$ & $81.54 * \pm 8.55$ & $78.04 * \pm 5.24$ & $117.24 \pm 8.06$ & $116.10 \pm 6.07$ & $122.00 \pm 7.75$ & $120.50 \pm 7.45$ \\
\hline $\begin{array}{l}\text { Central venous } \\
\text { pressure }(\mathrm{Cm})\end{array}$ & $5.20 \pm 2.81$ & $3.90 * \pm 2.66$ & $2.10 * \pm 0.71$ & $3.50 * \pm 3.21$ & $6.50 \pm 1.94$ & $6.10 \pm 1.93$ & $5.20 \pm 1.90$ & $4.40 \pm 3.06$ \\
\hline $\begin{array}{l}\text { Respiration rate } \\
(\mathrm{movt} / \mathrm{min})\end{array}$ & $10.80 \pm 2.15$ & $12.80 \pm 2.07$ & $14.40 \pm 1.65$ & $16.40 \pm 3.35$ & $16.40 \pm 3.35$ & $13.60 \pm 1.25$ & $16.00 \pm 2.28$ & $15.40 \pm 3.03$ \\
\hline $\begin{array}{l}\text { Body temperature } \\
(\mathrm{F})\end{array}$ & $99.0 \pm 0.84$ & $99.2 \pm 0.95$ & $100.6 \pm 0.82$ & $100.5 \pm 0.87$ & $92.4 \pm 2.03$ & $99.2 \pm 0.20$ & $99.9 \pm 0.20$ & $98.1 \pm 1.70$ \\
\hline $\begin{array}{l}\text { Hematocrit } \\
(\mathrm{PCV})(\%)\end{array}$ & $30.4 \pm 1.70$ & $30.0 \pm 1.38$ & $28.4 \pm 1.60$ & $25.8 * \pm 1.49$ & $24.4 * \pm 1.85$ & $26.6 * \pm 1.32$ & $26.0 * \pm 1.64$ & $26.6 \pm 1.34$ \\
\hline $\begin{array}{l}\text { Hemoglobin } \\
(\mathrm{g} / \mathrm{dl})\end{array}$ & $11.30 \pm 0.19$ & $10.8 \pm 0.76$ & $9.95 \pm 0.62$ & $8.69 * \pm 0.72$ & $7.92 * \pm 0.76$ & $8.55^{*} \pm 0.57$ & $9.08 * \pm 0.47$ & $8.77 * \pm 0.61$ \\
\hline
\end{tabular}

*Significant at $1 \%$ level; No. Of animals in each group $=5$. 


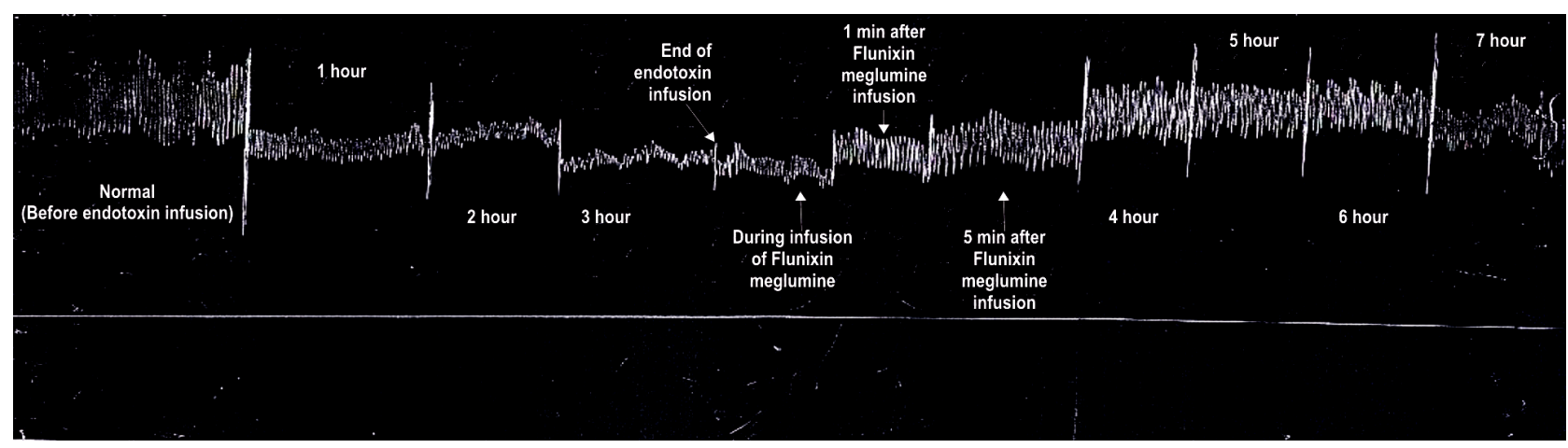

Figure 1. Blood pressure pattern during endotoxin infusion and after Flunixin meglumine infusion in an endotoxemic buffalo calf.

MAP after Flunixin meglumine may be due to the fact that NSAIDS like flunixin meglumine, Ketoprofen and Ketorolac are cyclo oxygenase inhibitor and prevents the formation of prostaglandins including $\mathrm{PGI}_{2}$ and hence improves tissue perfusion [1].

The normal CVP was $3.10 \pm 0.93 \mathrm{~cm}$ (Table 1) and $5.20 \pm 2.81 \mathrm{~cm}$ saline (Table 2) which is lower than $8.30 \pm 1.67 \mathrm{~cm}[11]$. There was a significant fall in CVP throughout endotoxin infusion from $1^{\text {st }}$ to $3^{\text {rd }}$ hour (Table 1 and 2). The fall in CVP may be due to peripheral pooling of blood [6]. According to Singh (1979), [12] failure of capacitance changes due to lack of venous constriction contributes to reduction in CVP. After Flunixin meglumine, CVP showed a marked increase at 4 hour (Table 1) and its level was non-significantly lower than the pre-infusion value. Similar findings have been reported by [13] but in group-2, CVP was above normal pre-infusion level at 4, 5 and 6 hour indicating beneficial effect of the infusion of hypertonic saline followed by flunixin meglumine.

The normal respiration rate was $11.80 \pm 1.20$ movt./ min (Table 1) and $10.80 \pm 2.15 \mathrm{movt} . / \mathrm{min}$. (Table 2) which is close to $7.20 \pm 0.47$ to $9.20 \pm 1.36 \mathrm{movt} / \mathrm{min}$ as reported by Singh et al., 2002 [3]. Under the influence of endotoxin, the respiration rate increased significantly and after flunixin meglumine infusion its value was non-significantly higher than the normal at $7^{\text {th }}$ hour (table 1). Similar effect of endotoxin on respiration rate has earlier been reported in mature cattle and cow calves $[1,14]$. The markedly elevated respiratory rate in group-I observed throughout the endotoxin infusion upto 3 hours indicated severe effects of endotoxin which may be due to the fact that cattle in comparison to other species have more abundant smooth muscle in the pulmonary vascular tree which may partially or completely explain so extreme response of lungs of cattle to endotoxin leading to pulmonary edema, atelactasis and respiratory acidosis. This is true not only for calves but also for mature cattle and the onset of clinical respiratory signs can be detected minutes after E. coli endotoxin administration [3].
The normal body temperature was observed to be $100.88 \pm 0.69^{\circ} \mathrm{F}$ (Table 1) and $99.0 \pm 0.84^{\circ} \mathrm{F}$ (Table 2) which is lower than $102.2^{\circ} \mathrm{F}$ as reported earlier [15]. There was a non-significant decrease in body temperature with in normal range during endotoxin infusion and after treatment with Flunixin meglumine. The normal PCV was found to be $35.20 \pm 1.43 \%$ (Table 1) and $30.40 \pm$ $1.70 \%$ (Table 2) which was similar to $29.0 \pm 4.0 \%$ to $35.0 \pm 6.0 \%$ [15]. Non-significant decrease in PCV was seen during endotoxin infusion and after infusion of Flunixin meglumine (Table 1). Similar findings have been reported in neonatal calves by [1]. Flunixin meglumine infusion treatment did not change PCV significantly (Table 1).

The normal haemoglobin was $12.51 \pm 0.28 \mathrm{~g} \%$ (Table 1) and $11.30 \pm 0.19 \mathrm{~g} \%$ (Table 2) which is close to $9.5 \pm$ 1.30 to $11.40 \pm 1.80 \mathrm{~g} \%$ [15] and $10.44 \pm 0.36$ to $11.40 \pm$ $0.38 \mathrm{~g} \%$ [6]. The mean $\mathrm{Hb}$ level showed a significant decrease at $3^{\text {rd }}$ hour of start of endotoxin infusion in both groups. After $\mathrm{FM}$ treatment, the $\mathrm{Hb}$ reached close to normal value (Table 1). A significant $(\mathrm{P}<0.01)$ fall in hematocrit and hemoglobin was observed at 3, 4, 5 and 6 hours after start of endotoxin infusion in group- 2 endotoxemic buffalo calves which may be due to the hemodilution caused by hypertonic saline as i.v. infusion of HSS causes rapid expansion in plasma volume and redistribution of the cardiac output towards the splanchnic circulation in calves given E. coli endotoxin [13].

The i.v.infusion of flunixin meglumine not only successfully raised systolic, diastolic, pulse and mean arterial pressure to normal pre-infusion value (Figure 1) but alleviated the clinical symptoms developed due to endotoxin infusion observed earlier. Flunixin meglumine is a cyclo-oxyoenase inhibitor and prevents the formation of prostaglandins, responsible for inflammatory response $[16,1]$. The Non steroidal anti inflammatory drugs like flunixin meglumine are beneficial in the management of endotoxemia and when used in combination with hypertonic saline solution, it has the additional advantage of bringing CVP to level above pre-infusion levels for 
some time.

From the results of the present investigation, it can be concluded that I.V. infusion of Flunixin meglumine alone and in combination with hypertonic saline solution in endotoxemic buffalo calves effectively restores the various hemodynamic parameters like systolic, diastolic, mean arterial and central venous pressure and body temperature close to or non-significantly below normal pre-infusion values thereby providing immediate resuscitation thus providing clinician valuable time to plan further long time treatment.

\section{REFERENCES}

[1] Semrad, S.D. (1993) Comparative efficiency of flunixin, ketoprofen and ketorolac for treating endotoxemine neonatal calves. American Journal of Veterinary Research, 54, 1511-1516.

[2] Ng, S.W., Zhang, H., Hedge, A. and Bhatia, M. (2008) Role of preprotachykinin-A gene products on multiple organ injury in LPS- induced endotoxemia. Journal of leucocyte Biology, 83, 288-95.

[3] Singh, D.V., Singh, R.V. and Sodhi, S.P.S. (2002) Effect of HSS on haemodynamics of endotoxemic buffalo calves. Indian Journal of Animal Sciences, 72, 10831086.

[4] Dacie, J.V. and Lewis, S.M. (1975) Practical hematology. 5th Edition, Churchill Livingstone, London.

[5] Snedecor, G.W. and Cochran, W.G. (1976) Statistical methods. Iowa State College Printing Press, Iowa, USA.

[6] Singh, D.V., Singh, R.V. and Sodhi, S.P.S (2005) Effect of blood transfusion in combination with Dextran-40 and hypertonic Saline Solution on cardiopulmonary haemodynamics of endotoxic shock in buffalo calves. Veterinary Research Communication, 29, 421-430. doi:10.1007/s11259-005-1434-x

[7] Singh, K., Krishnamurthy, D. and Peskin, P.K. (1997) Endotoxin shock with and without dexamethasone pre- treatment in anaesthetized buffalo calves. II. Indian Journal of Veterinary Surgery, 18, 8-11.

[8] Margolis, J.H., Buttons, G.D. and Fessler, J.F. (1987). The efficacy of dexamethasone and flunixin meglumine in treating endotoxin induced changes in calf. Veterinary Research Communications, 11, 479-491. doi:10.1007/BF00380630

[9] Jean, G.S., Constable, P.D., and Yvorchok, M. (1993) The clinical use of hypertonic saline solution in food animals with haemorrhagic and endotoxic shock. Agricultural Practice, 14, 6-11.

[10] Olson, N.C., Hellyer, P.W. and Dodam, J.R. (1995) Mediators and vascular effects in response to endotoxin. British Veterinary Journal, 151, 489-521. doi:10.1016/S0007-1935(05)80023-5

[11] Sobti, V.K., Mirakhur, K.K., Krishnamurthy, D. and Nigam, J.M. (1981) Ringer's lactate and homologous blood transfusion in hemorrhagic shock in buffalo calves. Indian journal of experimental Biology, 19, 371-374.

[12] Singh, J. (1979). An investigation into Patho-Physiology and treatment of shock in bovines, Ph.D. dissertation, Punjab Agricultural University, Ludhiana, India.

[13] Constable, P.D., Schmall, M., Muir, W.W., Hoffsis, G.F. and Shertel, E.R. (1991) Haemodynamic response of endotoxemic calves to treatment with small volume HSS. American Journal of Veterinary Research, 52, 981-989.

[14] Dupe, R., Bywater, R.J. and Goddard, M. (1993) A hypertonic saline infusion in treatment of experimental shock in calves and clinical shock in dogs and cats. Veterinary Record, 133, 585-590.

[15] Constable, P.D., Gohar, H.M., Morin, D.E. and Thurmon J.C. (1996). Use of hypertonic saline- dextrin solution to resuscitate hypovolemic calves with diarrhoea. American Journal of Veterinary Research, 57, 97-104.

[16] Kopcha, M. and Ahl, A.S. (1989) Experimental use of flunixin meglumine and phenyl butazone in food producing animals. Journal of American Veterinary Research Communications, 11, 479-491. 